HNF-EP-0496

Revision 2

UC-2000

\title{
Project Hanford Management Contract Pollution Prevention Program Implementation Plan
}

B. G. Place

Rust Federal Services of Hanford, Inc.

Date Published

December 1996

Prepared for the U.S. Department of Energy Assistant Secretary for Environmental Management

Under Project Hanford Management Contract DE-AC06-96RL13200 


\section{RELEASE AUTHORIZATION}

Document Number: HNF-EP-0496, Rev. 2

Document Title: Project Hanford Management Contract Pollution

Prevention Program Implementation Plan

Release Date: $\quad 12 / 31 / 96$

This document was reviewed following the procedures described in WHC-CM-3-4 and is:

\section{APPROVED FOR PUBLIC RELEASE}

WHC Information Release Administration Specialist:

2. W. Putelene

V. L. Birkland

$12 / 31 / 96$ 
LEGAL DISCLAIMER

This report was prepared as an account of work sponsored by an agency of the United States Government. Neither the United States Government nor any agency thereof, nor any of their employees, nor any of their contractors, subcontractors or their employees, makes any warranty, express or implied, or assumes any legal liability or responsibility for the accuracy, completeness, or any third party's use or the results of such use of any information, apparatus, product, or process disclosed, or represents that its use would not infringe privately owned rights. Reference herein to any specific commercial product, process, or service by trade name, trademark, manufacturer, or otherwise, does not necessarily constitute or imply its endorsement, recommendation, or favoring by the United States Government or any agency thereof or its contractors or subcontractors. The views and opinions of authors expressed herein do not necessarily state or reflect those of the United States Government or any agency thereof.

This report has been reproduced from the best available copy. Available in paper copy and microfiche.

Available to the U.S. Department of Energy and its contractors from

Office of Scientific and Technical Information

P.O. Box 62

Oak Ridge, TN 3783!

(615) 576.8401

Available to the public from the U.S. Department of Commerce National Technical Information Service

5285 Port Royal Road

Springfield, VA 22161

(703) 487.4650

Frinted in the United States of Americs

DISCLM-1.CHP $(1-91)$ 
THE F:ATENTONALLY 1. $\therefore \mathrm{LNNK}$ 


\section{CONTENTS}

GLOSSARY

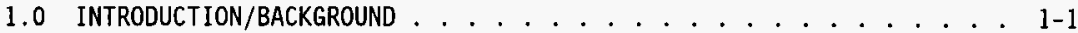

1.1 PURPOSE OF IMPLEMENTATION PLAN . . . . . . . . . . . . . . . . 1-1

1.2 ACTIVITY SCOPE . . . . . . . . . . . . . . . . . . . . . . $1-2$

1.3 LEGAL AND POLICY BACKGROUND . . . . . . . . . . . . . . . . . . 1-5

2.0 ORGANIZATION AND INFRASTRUCTURE .................... .1

2.1 PROGRAM INTEGRATION AND COORDINATOR NETWORK . . . . . . . . $2-1$

2.2 U.S. DEPARTMENT OF ENERGY PROGRAM PARTICIPATION . . . . . . . $2-1$

2.3 PROGRAM ORGANIZATION AND RESPONSIBILITIES . . . . . . . . . . . 2 2-1

2.3.1 Rust Federal Services of Hanford, Inc., Pollution

Prevention/Waste Minimization Group . . . . . . . . . 2-2

2.3.2 Project Hanford Management Contract Recycling . . . . . 2-3

2.3.3 Project Hanford Management Contract Procurement . . . . 2-3

2.3.4 Project Hanford Management Contract Waste

Generator Group Pollution Prevention/

Waste Minimization Programs ........... 2-3

3.0 PROGRAM DEVELOPMENT . . . . . . . . . . . . . . . . . . . 3-1

3.1 POLICY . . . . . . . . . . . . . . . . . . . . . . 3-1

3.1.1 U.S. Department of Energy's Commitment to

Pollution Prevention/Waste Minimization ........ . 3-1

3.1.2 Contractor Pollution Prevention/Waste Minimization

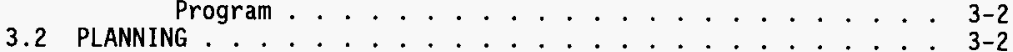

3.3 STRATEGY . . . . . . . . . . . . . . . . . . . $3-2$

3.3.1 Sitewide Initiatives ............. 3-3

3.3.2 Generator Groups . . . . . . . . . . . . . . . 3-3

3.4 PROGRAM OBJECTIVES .................. . . . . . . . . . 3

3.4.1 Key Objectives .................. . 3-4

3.4.2 Strategic Objectives .............. . . 3-4

3.5 GOALS . . . . . . . . . . . . . . . . . . 3-5

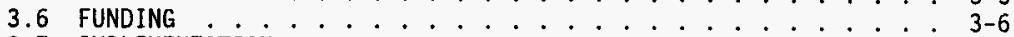

3.7 IMPLEMENTATION . . . . . . . . . . . . . . . . . . . . . . $3-6$

3.8 PERSONNEL . . . . . . . . . . . . . . . . . . . . . . 3-6

3.9 OPERATING PROCEDURES . . . . . . . . . . . . . . . . . . . . . $3-6$

3.10 QUALITY ASSURANCE . . . . . . . . . . . . . . . . . . . . 3-6

4.0 EMPLOYEE INVOLVEMENT . . . . . . . . . . . . . . . . . . . . 4-1

4.1 TRAINING ...................... . . . . . . . . . . . .

4.1.1 Pollution Prevention Opportunity

Assessment Training ............... . 4-1

4.1.2 Training for Incorporating Poliution
Prevention into Design . . . . . . . . . . 4-1

4.1.3 General Employee and Hazardous
Waste Training .................. . . . . 4-1

4.2 AWARENESS . . . . . . . . . . . . . . . . . . . . . . . . . . 4-2

4.3 INCENTIVES . . . . . . . . . . . . . . . . . . . . . . $4-2$ 
HNF-EP-0496, ReV. 2

CONTENTS (cont'd)

5.0 TRACKING . . . . . . . 5-1

5.1 EMERGENCY PLANNING AND COMMUNITY RIGHT-TO-KNOW ACT

MATERIAL INVENTORY TRACKING ............... . 5-1

5.2 WASTE TRACKING . . . . . . . . . . . . . . . . 5-1

5.3 POLLUTION PREVENTION OPPORTUNITY ASSESSMENT TRACKING .................. 5-2

5.4 COST TRACKING AND ACCOUNTING . . . . . . . . . . . . 5-2

5.4.1 Cost Tracking ................... 5-2

5.4.2 Cost Accounting ................ $5-3$

6.0 REPORTING . . . . . . . . . . . . . . . . . . 6-1

6.1 COMPLIANCE REPORTING . . . . . . . . . . . . . . . . $6-1$

6.2 REPORTS TO THE U.S. DEPARTMENT OF ENERGY . . . . . . . . . . $6-1$

7.0 SITEWIDE WASTE REDUCTION . . . . . . . . . . . . . . . . 7-1

7.1 TOXICS REDUCTION/MATERIAL SUBSTITUTION . . . . . . . . . 7-1

7.2 MATERIAL EXCHANGE ................... . . $7-1$

7.3 RECYCLING/REUSE .................... . . . . . . . . . . . . .

7.4 AFFIRMATIVE PROCUREMENT .............. . . . . . .

8.0 TECHNICAL ASSISTANCE . . . . . . . . . . . . . . . . . 8-1

8.1 GOAL SETTING . . . . . . . . . . . . . . . . 8-1

8.2 BASELINE DETERMINATION . . . . . . . . . . . . . . . . . . . $8-1$

8.3 OPPORTUNITY ASSESSMENTS . . . . . . . . . . . . . . . . 8-1

9.0 INFORMATION AND TECHNOLOGY EXCHANGE ................. . . . $9-1$

9.1 SEMINARS, WORKSHOPS, AND MEETINGS .............. . . $9-1$

9.2 ELECTRONIC INFORMATION RESOURCES ............... . . . 9 - 1

9.3 OUTREACH AND PUBLIC RELATIONS . . . . . . . . . . . . . . . 9-1

10.0 RESEARCH AND DEVELOPMENT ................... . . 10-1

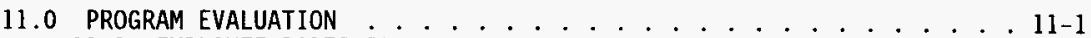

11.1 EMPLOYEE PARTICIPATION . . . . . . . . . . . . . . 11-1

11.2 POLLUTANT AND WASTE REDUCTION PERFORMANCE

12.0 REFERENCES ....................... . . . . . . . 12-1

\section{APPENDICES}

A FLUOR DANIEL HANFORD POLLUTION PREVENTION AND WASTE MINIMIZATION POLICY . . . . . . . . . . . . . . . . . . . . A-i

B U.S. ENVIRONMENTAL PROTECTION AGENCY WASTE MINIMIZATION PROGRAM ELEMENTS GUIDANCE COMPLIANCE MATRIX . . . . . . . . . . . . . B-

C GENERATOR GROUP POLLUTION PREVENTION/WASTE MINIMIZATION PROGRAM DOCUMENTATION ........................... c-i 
HNF-EP-0496, Rev. 2

\section{LIST OF FIGURES}

1-1 Pollution Prevention Program Scope ............ 1-3

1-2 Pollution Prevention Program Hierarchy . . . . . . . . . . . 1-4 


\section{GLOSSARY}

\section{ABBREVIATIONS AND ACRONYMS}

$\begin{array}{ll}\text { BWHC } & \text { B\&W Hanford Company } \\ \text { BWP } & \text { B\&W Protec, Inc. } \\ \text { CERCLA } & \text { Comprehensive Environmental Response, Compensation and } \\ & \text { Liability Act } \\ \text { CFR } & \text { Code of Federal Regulations } \\ \text { DESH } & \text { Duke Engineering \& Services Hanford, Inc. } \\ \text { DESNW } & \text { DE\&S Northwest, Inc. } \\ \text { DOE } & \text { U.S. Department of Energy } \\ \text { DOE-HQ } & \text { U.S. Department of Energy-Headquarters } \\ \text { DOE-RL } & \text { U.S. Department of Energy, Richland Operations office } \\ \text { DYN } & \text { DynCorp Tri-Cities Services, Inc. } \\ \text { ECOTogy } & \text { Washington State Department of Ecology } \\ \text { E0 } & \text { Executive Order } \\ \text { EM } & \text { Environmental Management } \\ \text { EPA } & \text { U.S. Environmental Protection Agency } \\ \text { FDH } & \text { Fluor Daniel Hanford, Inc. } \\ \text { FDNW } & \text { Fluor Daniel Northwest, Inc. } \\ \text { FR } & \text { Federal Register } \\ \text { FY } & \text { Fiscal Year } \\ \text { GSA } & \text { General Services Administration } \\ \text { HGET } & \text { Hanford General Employee Training } \\ \text { HMID2 } & \text { Hazardous Material Inventory Database 2 } \\ \text { LMHC } & \text { Lockheed Martin Hanford Corporation } \\ \text { LMSI } & \text { Lockheed Martin Services, Inc. } \\ \text { NHC } & \text { Numatec Hanford Corporation } \\ \text { P2/Wmin } & \text { Pollution Prevention/Waste Minimization } \\ \text { P2OA } & \text { Pollution Prevention Opportunity Assessment } \\ \text { PCB } & \text { polychlorinated biphenyl } \\ \text { PHMC } & \text { Project Hanford Management Contract } \\ \text { POC } & \text { points of contact } \\ \text { ppm } & \text { parts per million } \\ \text { RCRA } & \text { Resource Conservation and Recovery Act of 1976 } \\ \text { RFS } & \text { Rust Federal Services Northwest } \\ \text { RFSH } & \text { Rust Federal Services of Hanford, Inc. } \\ \text { SESC } & \text { SGN Eurisys Services Corp. } \\ \text { SWITS } & \text { Solid Waste Information and Tracking System } \\ \text { TSCA } & \\ \text { WAC } & \\ \text { DEFINITIONS } & \end{array}$

Generator. Each contractor within the scope of the Pollution Prevention/Waste Minimization (P2/WMin) Program whose activities or processes produce waste.

Generator Group. As defined by the responsible contractor, any discrete activity, project, or facility whose act or process produces waste.

Goal. A specific result toward which efforts are directed. 
Hazardous Substance. Any hazardous substance 1 isted as a hazardous substance in the Emergency Planning and Community Right-to-Know Act and any further updates, and all ozone depleting compounds as defined by the Montreal Protocol of October 1987 and any further updates of the protocol.

Hazardous Waste. Those solid wastes that exhibit any of the characteristics of hazardous waste identified in 40 Code of Federal Regulations (CFR) 261, Subpart C (e.g., ignitable, corrosive, reactive, acutely hazardous, or acutely toxic), or that are listed in 40 CFR 261, Subpart D, "List of Hazardous Waste."

Low-Level Waste (LLW). Waste that contains radioactivity and is not classified as high-level waste, transuranic waste, or spent nuclear fuel or byproduct material as defined by DOE Order 5820.2A (DOE 1988). Test specimens of fissionable material irradiated for research and development only, and not for the production of power or plutonium, may be classified as low-level waste, provided the concentration of transuranic is less than 100 nanocuries per gram $(\mathrm{nC} i / g)$.

Mixed Waste. Waste containing both radioactive and hazardous components as defined by the Atomic Energy Act of 1954 and the Resource Conservation and Recovery Act of 1976 (RCRA), respectively.

Non-Routine Waste. Non-routine encompasses a complex range of activities including environmental restoration of contaminated media (soil, groundwater, surface water, sediments, etc.); stabilization of nuclear and non-nuclear (chemical) materials; and deactivation and decommissioning (D\&D) (including decontamination of facilities). Non-routine waste consists of one-time operations waste produced from environmental restoration program activities, including primary and secondary wastes associated with retrieval and remediation operations, "legacy wastes," and wastes from D\&D/transition operations. It also includes all Toxic substances Control Act of 1976 (TSCA) regulated wastes, such as polychlorinated biphenyl (PCB)-contaminated fluids and/or equipment.

Pollution Prevention. The use of materials, processes, or practices that reduce or eliminate the creation of pollutants or wastes at the source. It includes practices that reduce the use of hazardous and nonhazardous materials, energy, water, or other resources as well as those that protect natural resources through conservation or more efficient use.

Process Waste Water. Any water produced during manufacturing or processing operations that comes into direct contact with or results from the production or use of any raw material, intermediate product, finished product, by-product, or waste product. This determination is independent of the level and/or nature of the contaminants. Additionally, process waste waters are liquid wastes that are piped directly to a permitted (onsite) waste treatment facility where treatment may consist of neutralization, evaporation, or placement in a settling or percolation pond, etc. This term does not include the liquid discharges to publicly owned treatment works, which are governed by U.S. Environmenta1 Protection Agency (EPA) - or state-issued nationa1 pollutant discharge elimination system permits, or local pretreatment standards. 
Examples of process waste water include cooling water from air compressor systems, air conditioners, and heating systems; boiler or cooling tower blowdown; ion-exchange regeneration waste water; and laboratory operations waste water. It does NOT include nonprocess waste waters such as storm water, well purge water, irrigation drainage, fire-fighting and hydrant flushings, lawn watering, pavement wash waters, vehicle waste water, etc. (DOE 1996).

RCRA-Regulated Waste. Solid waste, not specifically excluded from regulations under 40 CFR 261.4, "Identification and Listing of Hazardous Waste," or delisted by petition, that is either a listed hazardous waste (40 CFR 261.30 to 261.33) or exhibits the characteristics of a hazardous waste (40 CFR 261.20 to 261.24).

Recycling. Recycling techniques are characterized as use, reuse, and reclamation techniques (resource recovery). Use or reuse involves the return of a potential waste material either to the originating process as a substitute for an input material or to another process as an input material. Reclamation is the processing or regeneration of a material to recover a useable product.

Routine 0perations Waste. Normal operations waste produced from any type of production, analytical, and/or research and development laboratory operations; treatment, storage, or disposal operations; "work-for-others;" or any periodic and recurring work that is considered ongoing. The term "normal operations" refers to the type of ongoing process (e.g., production) not the specific activity that produced the waste. Periodic laboratory or facility clean-outs and spill cleanups which occur as a result of these processes are al so considered normal operations.

Sanitary Waste. Wastes, such as garbage, that are generated by normal housekeeping activities and are not hazardous or radioactive (DOE 1996).

Source Reduction. The elimination or reduction of waste generation at the source. Source reduction activities and techniques include substitution of less hazardous materials, process optimization or modification, technology changes and administrative changes (inventory control), and housekeeping practices (waste segregation). Source reduction results in reducing or eliminating potential waste material exiting from a process.

Spent Nuclear Fuel. Fuel that has been withdrawn from a nuclear reactor following irradiation, but that has not been reprocessed to remove its constituent elements.

State-Only Requlated Waste. Any other hazardous waste not specifically regulated under TSCA or RCRA, such as used oil, which may be regulated by Washington State Department of Ecology (Ecology) under Washington Administrative Code (WAC) 173-303.

Transuranic Waste. Without regard to source or form, waste that is contaminated with alpha-emitting transuranium radionuclides with half-lives greater than 20 years and concentrations greater than $100 \mathrm{Nci} / \mathrm{g}$ at the time of assay. Heads of Field Elements can determine that other alpha contaminated wastes, peculiar to a specific site, must be managed as transuranic waste (DOE 1988). 
Treatment. Technological processes that reduce the quantity, toxicity, or mobility of waste. Examples include, but are not limited to, incineration, vitrification, neutralization, chemical extraction, physical separation, and solidification/stabilization technologies.

TSCA-Regulated Waste. Hazardous chemical wastes, both liquid and solid, containing more than 50 parts per million (ppm) of PCBs (DOE 1996).

Waste Reduction. Reduction of the total amount of waste that is generated and disposed of by U.S. Department of Energy (DOE) operations through waste minimization and treatment activities.

Waste Minimization. Elimination or minimization of the generation of waste before treatment, storage, or disposal. Waste minimization is any source reduction or recycling activity that results in the reduction of total quantity of waste or the reduction of toxicity of waste, provided that reduction is consistent with the general goal of minimizing present and future threats to human health and the environment. 
HNF-EP-0496, Rev. 2

This page intentionally left blank. 
HNF-EP-0496, Rev. 2

\section{POLLUTION PREVENTION/WASTE MINIMIZATION PROGRAM IMPLEMENTATION PLAN}

\subsection{INTRODUCTION/BACKGROUND}

\subsection{PURPOSE OF IMPLEMENTATION PLAN}

This plan documents the Project Hanford Management Contract (PHMC) Pollution Prevention/Waste Minimization (P2/WMin) Program. The subject implementation plan has been updated to reflect the Fiscal Year (FY) 1997 contract structure in which Fluor Daniel Hanford, Inc. (FDH) is the management and integration contractor. The P2/WMin Program scope includes FDH as the principa1 PHMC contractor, and B\&W Hanford Company (BWHC), Duke Engineering \& Services Hanford, Inc. (DESH), Lockheed Mart in Hanford Corporation, (LMHC), Numatec Hanford Corporation (NHC), Rust Federal Services of Hanford, Inc. (RFSH), and DynCorp Tri-Cities Services, Inc. (DYN) as PHMC contractors, as well as subcontracting enterprise companies, such as Fluor Daniel Northwest, Inc. (FDNW), Lockheed Martin Services, Inc. (LMSI), and Rust Federal Services Northwest (RFS), which provide engineering, operation, construction, maintenance, and computer services for the Hanford Site. The P2/WMin Program scope also includes all other subcontractor-affiliated enterprise companies, such as B\&W Protec, Inc. (BWP), DE\&S Northwest, Inc. (DESNW), and SGN Eurisys Services Corp. (SESC).

The PHMC contractors are committed to implementing an effective P2/WMin Program as identified in the Hanford Site Waste Minimization and Pollution Prevention Awareness Program Plan (DOE-RL 1996a). This plan provides specific information on how the PHMC P2/WMin Program will develop and implement the goals, activities, and budget needed to accomplish program implementation. This plan will guide the development and implementation of the program as required by the P2/WMin awareness plan (DOE-RL 1996a) and the FDH prime contract (DOE-RL 1996b).

Under the PHMC, P2/WMin applies to Hanford Site facilities and services. The contractual structure that implements this comprehensive application is discussed below. Fundamentally, this contractual structure combines the following four elements:

1. FDH's implementation of the U.S. Department of Energy's (DOE) P2/WMin policy.

2. FDH's contractual requirements in the prime contract (Sections $B$, C, D, and I) (DOE-RL 1996b).

3. Flowdown of contractual requirements from FDH to RFSH and other subcontractors.

4. The identification of $P 2 / W M i n$ as a cross-cutting service in the prime contract (DOE-RL 1996b) and RFSH subcontract. 
FDH has adopted a policy concerning pollution prevention and waste minimization that must also be adopted by subcontractors on the basis of flowdown of prime contract requirements to subcontracts (DOE-RL 1996b). FDH P2/WMin policy, which is presented in Appendix A, addresses the parameters of the current DOE pollution prevention policy (FDH 1996).

This plan will be distributed to PHMC contractor organizations and subcontractors with defined responsibilities. The policy, goals, objectives, and the strategy of the P2/WMin Program will be communicated to PHMC employees by site communication media that include the issue of formal reports and plans, as well as information made available on the Hanford Home Page and articles in the Hanford Reach. The plan also can be used as a reference tool, along with the P2/WMin awareness plan (DOE-RL 1996a), for managers, operations personnel, and support staff to incorporate P2/WMin into all applicable activities. This implementation plan will be reviewed annually and revised as necessary. At a minimum, the implementation plan will be updated every 3 years.

\subsection{ACTIVITY SCOPE}

The scope of the PHMC P2/WMin Program includes source reduction, recycling, treatment, and resource and energy conservation, as shown schematically in Figure 1-1. P2/WMin is to be understood as a comprehensive term, the meaning of which includes the range and hierarchy of environmental management (EM) activities that comprise the PHMC P2/WMin Program. The program is an organized, comprehensive, and continual effort to reduce hazardous, radioactive, and sanitary wastes; to conserve resources; and to prevent or minimize pollutant releases to the environment from all PHMC contractor activities and operations.

In accordance with these policies, the hierarchical approach to EM, shown schematically in Figure 1-2, is applied to all types of pollution and waste generating activities. Pollution prevention and waste minimization, through source reduction, are the preferred option of the PHMC P2/WMin Program, followed by environmentally safe recycling. Treatment to reduce the quantity, toxicity, and/or mobility will be considered only when prevention or recycling are not possible or practical. Environmentally safe disposal is the last option. 
HNF-EP-0496, Rev. 2

Figure 1-1. Pollution Prevention Program Scope.

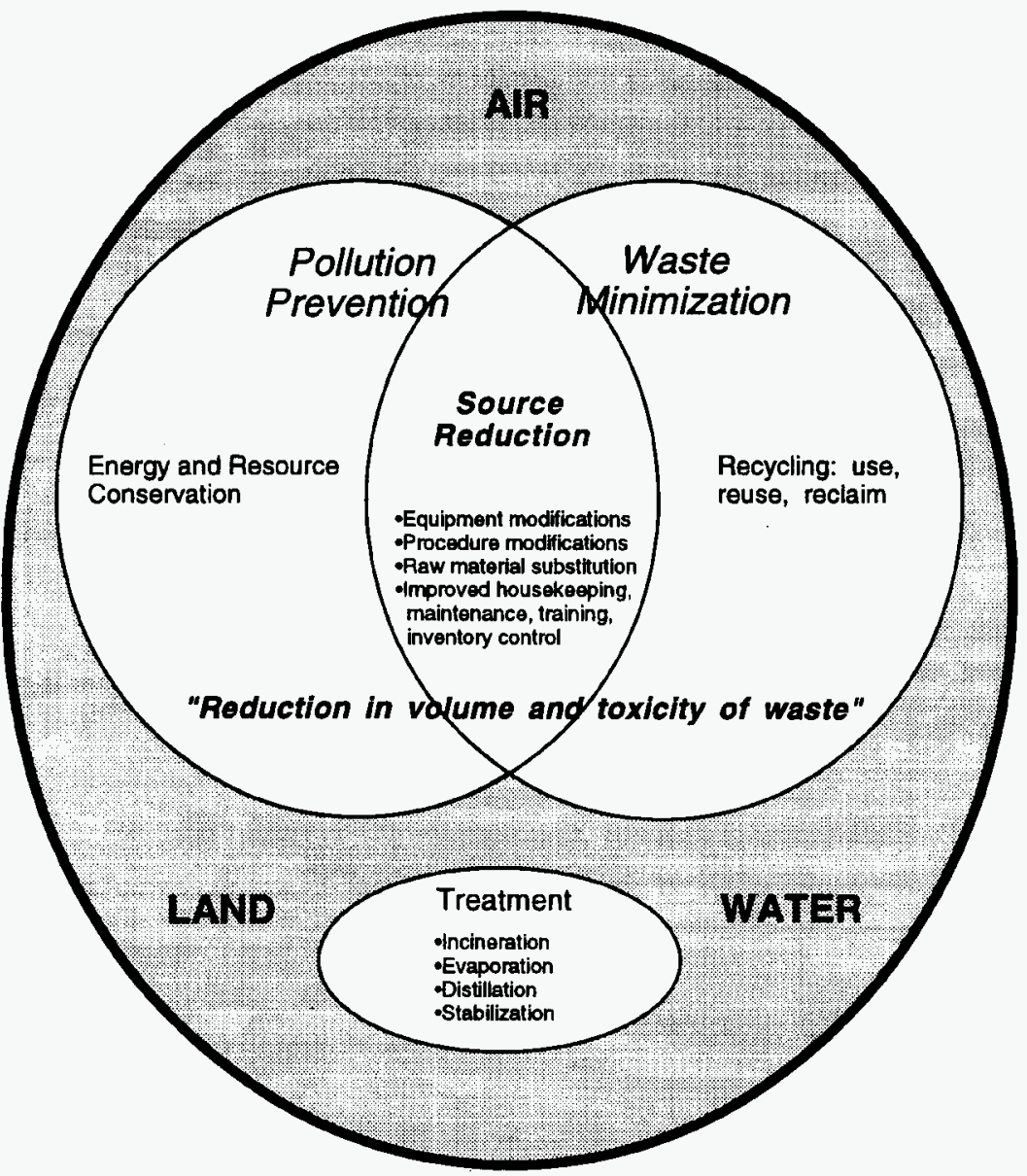


HNF-EP-0496, Rev. 2

Figure 1-2. Pollution Prevention Program Hierarchy.

\section{Source Reduction}

\section{Recycling}

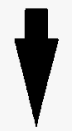

\section{Waste Treatment}

\section{Disposal}




\subsection{LEGAL AND POLICY BACKGROUND}

The P2/WMin Awareness Program Plan (DOE-RL 1996a) identifies a comprehensive list of legal and policy documents and agreements that guide and dictate various aspects of the P2/WMin Program. The P2/WMin Program is considered an integral part of the Hanford Site cleanup effort, as described in the PHMC statement of work. Accordingly, the regulatory and policy requirements for $\mathbf{P 2}$ /WMin include Federal and state laws, environmental regulations, Executive Orders (EO), DOE Orders, and agency and corporate policies. Appendix $B$ identifies waste minimization program documentation elements that satisfying regulatory compliance.

The cleanup of the Hanford Site is governed principally by an agreement signed in 1989 between the DOE, the U.S. Environmental Protection Agency (EPA), and the Washington State Department of Ecology (Ecology). This document, called the Hanford Facility Agreement and Consent Order (Tri-Party Agreement) (Ecology et a1. 1996), outlines a plan to clean up the site by the year 2028. Milestones in the agreement are focused on bringing the Hanford Site into compliance with the Comprehensive Environmental Response, Compensation and Liability Act (CERCLA) and the Resource Conservation and Recovery Act of 1976 (RCRA). 
HNF-EP-0496, Rev. 2

This page intentionally left blank. 
HNF-EP-0496, ReV. 2

\subsection{ORGANIZATION AND INFRASTRUCTURE}

\subsection{PROGRAM INTEGRATION AND COORDINATOR NETWORK}

The PHMC P2/WMin Program organization and infrastructure is designed to integrate and coordinate program activities among PHMC contractors and subcontractors. Current P2/WMin Program organization reflects the contractor organizational structure under the PHMC. Central to the Hanford Site P2/WMin organizational structure is the RFSH P2/WMin group, which coordinates the P2/WMin activities between the PHMC contractors and subcontractors.

Key projects, programs, and facilities have assigned $\mathrm{P} 2 /$ WMin points of contact (POCS) to interface directly with the RFSH P2/WMin group. The current list of P2/WMin POCs is available from the RFSH P2/WMin group. The scope of the interface activities includes identifying all generator group P2/WMin representatives, assigning RFSH P2/WMin staff to support individual generator group programs, holding quarterly meetings with Site representatives, and having consistent generator group programs for all contractors and subcontractors.

Program coordination will occur through meetings held at least quarterly. All program-related personnel and other interested parties will be invited to attend these meetings, which will provide the forum for sharing and exchanging important program information, including $\mathrm{P} 2 /$ WMin technologies and initiatives.

\subsection{U.S. DEPARTMENT OF ENERGY PROGRAM PARTICIPATION}

The DOE's pollution prevention mission is to minimize the generation and release of pollutants to the environment by implementing cost-effective pollution prevention technologies, practices, and policies with partners in government and industry. The DOE will simultaneously conduct its operations in such a way as to minimize impact on the environment, improve the safety of operations and energy efficiency, and promote the sustainable use of natural resources (DOE 1996).

The RFSH P2/WMin group will coordinate DOE complex-wide participation for the PHMC by developing and issuing program guidance that reflects DOE requirements and objectives and by communicating DOE requirements to PHMC organizations.

\subsection{PROGRAM ORGANIZATION AND RESPONSIBILITIES}

The PHMC P2/WMin Program is supported directly and implemented by the following organizations and programs: RFSH P2/WMin, DYN Recycling, FDH Procurement, and PHMC generator group P2/WMin Programs. The following is a breakdown of major responsibilities for the organizations and programs that support the program. Responsibilities correlate with the regulatory and DOE requirements that are identified in the Hanford Site P2/WMin awareness plan (DOE-RL 1996a). 


\subsubsection{Rust Federal Services of Hanford, Inc., Pollution Prevention/Waste Minimization Group}

The RFSH P2/WMin group organizes the PHMC P2/WMin Program and has been assigned the role of lead coordinator among PHMC contractors to support FDH in the development and implementation of the Sitewide program. The DOE-Richland Office Operations (DOE-RL) P2/WMin program manager will coordinate Site program activities through FDH. Some specific responsibilities of the RFSH P2/WMin group are as follows:

- Developing Sitewide program elements that encourage and facilitate P2/WMin

- Providing written P2/WMin guidance for PHMC contractors and subcontractors

- Establishing PHMC contractor waste reduction goals for routine waste generators

- Providing contractor/facility-specific pollution prevention training, Pollution Prevention Opportunity Assessment (P20A) training, and developing incentive and awareness programs

- Developing tracking and reporting systems

- Collecting information for reporting summary P2/WMin efforts to DOE and regulatory agencies

- Assisting in the establishment of generator group representatives and teams

- Assisting non-routine generator groups in establishing goals in accordance with 58 Federal Register (FR) 12856, "Federal Agency Compliance with Right-to-Know Laws and Pollution Prevention Requirements," and DOE goal-setting guidance established in Hanford Site Guide for Preparing and Maintaining Generator Group Pollution Prevention Program Documentation (DOE-RL 1996c)

- Assisting in obtaining management support and budget for P2/WMin activities

- Providing technical assistance to generator groups in development and implementation of their P2/WMin Programs

- Leading the development and implementation of Sitewide initiatives except for material exchange, recycling, and affirmative procurement

- Conducting quarterly pollution prevention meetings for all site contractors

- Championing technical pollution prevention initiatives

- Coordinating P2/WMin requirements for a11 PHMC contractors and subcontractors 
HNF-EP-0496, Rev. 2

- Responding to FDH requests from DOE-RL and DOE-Headquarters (DOE-HQ)

- Interpreting legis1ative and DOE P2/WMin Program requirements.

\subsubsection{Project Hanford Management Contract Recycling}

Under the PHMC, the subcontractor, DYN, has the responsibility for recycling. A few specific responsibilities of PHMC Recycling are as follows:

- Developing, implementing, and maintaining programs to recycle, reuse, and excess materials, commodities, and recoverable scrap with onsite and offsite end users

- Assisting and advising procurement organizations in the purchase of recycled and recyclable products.

\subsubsection{Project Hanford Management Contract Procurement}

PHMC Procurement responsibilities include the following:

- Implementing practices, where economically practicable, that minimize the procurement of $\mathrm{Cl}$ ass I ozone-depleting substances, which complies with 58 FR 12843, "Procurement Requirements and Policies for Ozone-Depleting Substances."

- Providing support to activities that reduce procurement of hazardous materials, as defined by RCRA, Washington Administrative Code (WAC) 173-303, and 58 FR 12873, "Federal Acquisition, Recycling, and Waste Prevention."

- Implementing an affirmative procurement program for products that have a recovered material content (DOE-RL 1996b, Section I).

\subsubsection{Project Hanford Management Contract Waste Generator Group Pollution Prevention/ Waste Minimization Programs}

Generator groups develop P2/WMin Programs in accordance with the recently issued EOs and other regulatory requirements identified in this plan and the Hanford Site P2/WMin Awareness Program Plan (DOE-RL 1996a) and the DOE-RL pollution prevention program documentation guide (DOE-RL 1996C). Programs are organized according to the key program elements identified in the DOE Pollution Prevention Program Plan (DOE 1996). Some specific generator group responsibilities are as follows:

- Establishing goals to minimize waste generation and reduce environmental releases (for routine waste generators only)

- Establishing resource requirements and activity schedules

- Prioritizing pollutants and waste streams 
HNF-EP-0496, ReV. 2

- Establishing P2OA teams

- Performing P20As on priority waste streams and identifying costeffective P2/WMin opportunities

- Impiementing cost-effective P2/WMin opportunities

- Incorporating P2/WMin into the design of new projects or activities

- Evaluating program implementation and performance

- Participating in the Sitewide program

- Implementing corrective actions

- Documenting and monitoring programs through maintaining the program documentation identified in Appendix $C$

- Meeting goals. 


\subsection{PROGRAM DEVELOPMENT}

The DOE-HQ Office of EM Office of Pollution Prevention (EM-77) has provided funding to the PHMC P2/WMin Program for development of program elements and tools to be used within the PHMC, Hanford Site, and DOE complex P2/WMin Programs. Some of the tools that were recently developed are design guidelines and training for the DOE complex on incorporating P2/WMin in the design of new or modified facilities. These tools, and others described in this plan, will be used to implement the program objectives. Key to this implementation will be to ensure that adequate resources and trained personnel are available to support the achievement of program goals and objectives.

\subsection{POLICY}

The DOE and the PHMC contractors are committed to establishing and maintaining an effective $\mathrm{P} 2 /$ WMin Program that implements the requirements of the Hanford Site P2/WMin Awareness Program Plan (D0E-RL 1996a). Adequate personnel, budget, training, and material will be provided to accomplish this objective.

\subsubsection{U.S. Department of Energy's Commitment to Pollution Prevention/Waste Minimization}

DOE has established P2/WMin as a priority and an integral part of its business and environmental strategy. In 1996, the Secretary of Energy formalized DOE's commitment to $\mathrm{P} 2$ /WMin by issuing ambitious waste reduction goals. Waste reduction is included in the DOE 10-year Strategic P1 an and pollution prevention has been raised to a national program. The Hanford Site P2/WMin budget is funded directly by DOE-HQ and is not part of the site baselines or prioritization.

DOE's Pollution Prevention Program Plan (DOE 1996) provides the following program guidance for individual sites:

- Establish senior management commitment to pollution prevention implementation

- Set quantitative, site-specific source reduction and recycling goals

- Institute performance measures

- Implement cost-saving pollution prevention projects

- Design pollution prevention into new products, processes, and facilities

- Ensure that site programs comply with Federal, state, and departmental requirements. 
The DOE-RL Manager has issued a written policy that establishes commitment to implementing the following: an effective P2/WMin Program at the Hanford Site, the Waste Minimization/Pollution Prevention (WMin/P2) Crosscut Plan (DOE 1994), the Pollution Prevention Program Plan (DOE 1996), and all applicable EOs. The policy is included in the Hanford Site P2/WMin awareness plan (DOE-RL 1996a).

\subsubsection{Contractor Pollution Prevention/ Waste Minimization Program}

In accordance with the laws and policies, DOE orders, EOs, regulatory requirements, EOs, and Washington Administration Codes (WACs) 1isted in the Hanford Site P2/WMin awareness plan (DOE-RL 1996a), the prime PHMC contractor, FDH, will develop and maintain a Sitewide P2/WMin Program. This program will be adhered to by all PHMC subcontractors.

The program will include the elements discussed under the FDH policy in Appendix A. This policy emphasizes the attainment of the Secretary of Energy's waste reduction goals, high Return-on-Investment waste minimization projects, and incorporating $\mathrm{P} 2 /$ WMin into new and modified facility designs.

\subsection{PLANNING}

The PHMC P2/WMin Program plan does not repeat general information contained in the Site plan. Instead, it identifies activities, schedules, and budgets to implement the program requirements stated in the Site plan.

The PHMC P2/WMin Program Implementation P1an also contains information not identified in the Site plan for generator groups to reference for documentation of their individual programs. Generators have program documentation on file to demonstrate that their P2/WMin Program meets Site requirements. Their program documentation consists of goals, budget, P20A, and pollution prevention reporting information (Appendix C). The RFSH P2/WMin group will support generator groups in their preparation of program documentation and in their implementation efforts. Goals and budget information will be developed annually. P20A and opportunity implementation will be ongoing. Reports will be prepared quarterly and annually. The Hanford Site Guide for Preparing and Maintaining Generator Group Pollution Prevention Program Documentation (DOE-RL 1996c) provides specific information on the requirements for these activities and how to document them.

\subsection{STRATEGY}

The PHMC P2/WMin Program strategy is to develop and implement a P2/WMin Program at the Hanford Site that achieves program objectives through effective and efficient P2/WMin methodologies tailored to generator activities and operations. This includes establishing goals and identifying priority activities and resource requirements. 
HNF-EP-0496, Rev. 2

An essential part of the strategy is to continually obtain accurate, current, and specific hazardous substance and energy use, pollutant release, and waste generation information on current activities. The Hazardous Material Inventory Database 2 (HMID2) and the Solid Waste Information and Tracking System (SWITS) will have an important role in establishing these baselines. Details on how these databases will support the program are provided in Section 5.0 of this plan. These databases will provide much of the necessary baseline information needed to identify priority areas for concentrating program resources. Those P2/WMin activities that will help achieve program goals and result in the highest safety, health, and environmental benefits, and the highest economic returns on investment will be given the highest priority for program personnel and resources. The strategy is implemented through Sitewide P2/WMin initiatives and through individua] generator group $\mathrm{P} 2$ /WMin activities.

\subsubsection{Sitewide Initiatives}

Coordinating and championing Sitewide initiatives is an essential element of implementing an efficient and cost-effective P2/WMin Program. Existing Sitewide initiatives include recycling programs for excess chemicals, paper and cardboard, wood, and scrap metal; a hazardous materials product substitution process, which provides information on nonhazardous alternative products having equivalent function.

\subsubsection{Generator Groups}

A primary element of the PHMC P2/WMin strategy is to modify generator activities to reduce pollutant releases and waste generation. The Hanford Site's mission of environmental restoration has changed the nature of most activities performed onsite from routine to discontinued or project-oriented activities. The strategy is to divide these different activities into pollutant/waste generator groups based on the nature of work being performed in order to facilitate the attainment of waste reduction goals. Generator groups are categorized in a manner consistent with established site programs and funding structures. Each generator group has access to an Environmental Compliance officer or environmental coordinator who can support the group in complying with P2/WMin regulatory requirements, and can work with generator group P2/WMin personnel and their management to ensure sufficient resources are allocated to $\mathrm{P} 2 / \mathrm{WMin}$ activities to meet all regulatory requirements.

Generator group activities are assessed for P2/WMin opportunities. This involves developing lists of priority pollutants and waste streams, performing P2OAs on priority activities, and identifying and implementing opportunities.

\subsection{PROGRAM OBJECTIVES}

The objectives of the PHMC P2/WMin Program are described below. These objectives were developed from regulatory and DOE requirements, and from input provided by PHMC P2/WMin Program contractors and generator group P2/WMin representatives. The key objectives identify the high-level results that will 
be achieved and the strategic objectives identify specific activities that will be accomplished to achieve the key objectives.

\subsubsection{Key Objectives}

Key objectives of the P2/WMin Program are as follows:

- Prevent pollution, minimize waste, and conserve energy and resources

- Meet or exceed the Secretary of Energy's waste reduction goals

- Comply with Federal, state, and DOE requirements for P2/WMin, waste minimization, waste reduction, and resource and energy conservation.

The strategic objectives, which support the key program objectives 1 isted above, are divided into four categories: infrastructure, development, implementation, and communication.

\subsubsection{Strategic Objectives}

3.4.2.1. Infrastructure. Strategic objectives of $\mathrm{P} 2 /$ WMin infrastructure are as follows:

- Obtain the necessary funding and management support to fully implement a successful P2/WMin Program

- Target and change policies, procedures, or practices that are barriers to $\mathrm{P} 2 /$ WMin

- Incorporate P2/WMin into the PHMC work planning and procedures system.

3.4.2.2. Development. Strategic objectives of $P 2 /$ WMin development are as follows:

- Establish waste generation baselines and projections for PHMC, broken down by individual generator groups

- Establish quantifiable P2/WMin goals, and identified priority activities for achieving measurable $\mathrm{P} 2 /$ WMin results

- Develop and implement P2/WMin tools and methodologies

- Contribute to the development of the DOE P2/WMin complex-wide program.

3.4.2.3. Implementation. Strategic objectives of P2/WMin implementation are as follows:

- Champion P2/WMin initiatives at the Hanford Site, within the DOE complex, and in the community 
HNF-EP-0496, ReV. 2

- Prepare and issue all required reports in a professional and timely manner

- Perform P20As on priority pollutant release and waste generating activities

- Identify and implement cost-effective P2/WMin opportunities

- Coordinate and promote high Return-on-Investment project proposals to fund P2/WMin activities on the Hanford Site

- Promote work force behavior change toward P2/WMin through training, awareness, and incentives

- Communicate P2/WMin goals, objectives, and implementation strategies to employees and to all levels of management

- Share P2/WMin techniques and accomplishments through onsite networking, technology transfer, outreach, and educational networks.

3.4.2.4. Communication. Strategic objectives of $P 2 / W M i n$ communication are as follows:

- Communicate P2/WMin goals, objectives, and implementation strategies to employees and to all levels of management.

Performance measures to track key activities representing these program objectives are discussed in Section 11.2.

\subsection{GOALS}

DOE-RL recently issued Hanford Site Guide for Preparing and Maintaining Generator Group Pollution Prevention Program Documentation (DOE-RL 1996c), which discusses waste reduction goals in detail. The goals for waste reduction distinguish between waste generated by routine and non-routine operations. The Secretary of Energy has established specific waste reduction goals for routine waste. PHMC contractors and subcontractors will also establish waste reduction goals for non-routine waste.

The RFSH P2/WMin group will issue recommended waste reduction goals for site contractor generator groups early in FY 1997. The guidance wi1l provide instruction on establishing goals achievable by December 1999 and annual goals to support the achievement of the 1999 goals. The RFSH P2/WMin group wil1 also provide support to generators and generator groups in establishing their goals.

Generators and generator groups must have their FY 1997 goals established by January 15, 1997. These goals will then be aggregated into PHMC P2/WMin Program goals and be provided to DOE-RL to meet the commitment in the Hanford Site P2/WMin awareness plan (DOE-RL 1996a) of finalizing Hanford Site goals by January 31,1997 . In subsequent years, goals will be established annually by generators and generator groups and aggregated at the PHMC P2/WMin Program level. 
The establishment of goals for routine and non-routine waste reduction is discussed in the detail the in the recently issued pollution prevention documentation guide (DOE-RL 1996c).

\subsection{FUNDING}

Generators and generator groups obtain funding from their cognizant Environmental Program Management area. Site $\mathrm{P} 2 /$ WMin funding includes budget for high Return-on-Investment P2/WMin projects that is available to generator groups.

\subsection{IMPLEMENTATION}

The pollution prevention documentation guide identifies the elements required to be implemented by the generator groups. The generator groups must demonstrate that their scheduling addresses these pollution prevention elements.

\subsection{PERSONNEL}

Program personnel responsible for $\mathrm{P} 2$ /WMin have been identified within the PHMC structure. Program personnel will work with management to secure adequate resources to support an effective P2/WMin Program.

\subsection{OPERATING PROCEDURES}

P2/WMin has been established in many PHMC procedures. Program requirements are established through the WHC-CM-7.5, Environmental Compliance Manual and through the pollution prevention program documentation guide for generators (DOE-RL 1996C). The inclusion of $\mathrm{P} 2 /$ WMin into facility design is being established through DOE-RL Order 6430.1C (DOE-RL 1990).

\subsection{QUALITY ASSURANCE}

PHMC contractor management, with support from Quality Assurance organizations, are responsible for implementing a quality P2/WMin Program. Management will ensure P2/WMin activities are effectively conducted and documented in accordance with DOE Directive $5700.6 \mathrm{C}$ and Quality Assurance Programs. Quality assurance activities may include independent assessment of the PHMC contractor and subcontractor P2/WMin activities to assess program quality and effectiveness. 


\subsection{EMPLOYEE INVOLVEMENT}

Employee involvement in $\mathrm{P} 2 /$ WMin has been increasing through establishing P2/WMin in all applicable training courses and through awareness. The specific activities identified below have been planned to continue to increase employee involvement and awareness.

\subsection{TRAINING}

General P2/WMin training is provided annually for all PHMC personnel through Hanford General Employee Training (HGET). The objective of this training is to make each employee aware of P2/WMin, its impact on the Site and the environment, and ways waste can be reduced and pollution prevented. Specific P2/WMin training is provided in other Site training courses. Many of these courses are described in greater detail in the Site P2/WMin plan. These courses are described in Section 4.1 .3 below. The RFSH P2/WMin group reviews and updates these courses annually.

\subsubsection{Pollution Prevention Opportunity Assessment Training}

The RFSH P2/WMin organization provides specific P20A training for groups involved in identifying and implementing P2/WMin opportunities. The training introduces participants to P2/WMin, describes the P2OA scope and process, and provides instruction for completing the P20A worksheets (DOE-RL 1996c).

\subsubsection{Training for Incorporating Pollution Prevention into Design}

A course is available to train facility designers, engineers, and project managers on methods to implement $P 2 /$ WMin into the design of new or modified facilities at the working level. The course is sponsored by the Quality Training Resource Center (QTRC) and is available to all Site personnel. The training program includes computerized training on the use of P2 Edge Software, introduction of the Pollution Prevention Design Assessment Guidance Manual (PNL 1995), descriptions of design successes, and other "design for environment" materials. This training is provided by individuals who have expertise in a particular area of design and $\mathrm{P}_{2} /$ WMin.

\subsubsection{General Employee and Hazardous Waste Training}

Generator-specific P2/WMin training is provided annually in the OSHA Hazardous Waste Operations training course. This course is required for a 11 employees working in treatment, storage, and disposal facilities. Training on the regulatory and PHMC P2/WMin requirements has been included in the Generator Hazard Communication and Waste Management Awareness Hazard Safety Training, the Container Waste Management, and the Waste Management Administration classes. 
HNF-EP-0496, ReV. 2

\subsection{AWARENESS}

The PHMC promotes P2/WMin awareness through the P2/WMin awareness campaign using existing Site media channels. Some of these awareness activities include recording entries in the annual P2/WMin accomplishments book and printing articles in the Hanford REACH. Each of these awareness tools highlight significant PHMC P2/WMin accomplishments.

\subsection{INCENTIVES}

PHMC employees are eligible for awards and recognition through DOE and PHMC contractor incentive campaigns and programs. Site personnel are eligible for receiving awards from DOE at annual $\mathrm{P} 2 /$ WMin conferences where individuals are recognized for their outstanding $\mathrm{P} 2$ /WMin accomplishments. In addition to these recognition programs, $\mathrm{PHMC}$ personnel are eligible to receive the White House Closing the Circle Award. 
HNF-EP-0496, Rev. 2

\subsection{TRACKING}

An important element of the P2/WMin Program is to develop and implement effective tracking systems. These systems will track material inventories, waste streams, P2OAs and implementation, and cost. This will involve the modification of existing databases, such as the HMID2 and SWITS, and the development of new systems.

\subsection{EMERGENCY PLANNING AND COMMUNITY RIGHT-TO-KNOW ACT MATERIAL INVENTORY TRACKING}

HMID2 is used to track hazardous materials and inventories at PHMC facilities. For purposes of the P2/WMin Program, it also will be used to identify which priority hazardous materials to reduce or eliminate. HMID2 is used to maintain current information on hazardous chemical and hazardous material inventories as defined by the Emergency Planning and Community Rightto-Know Act and 29 CFR 1910.1200, "Hazard Communication." The overall architecture for HMID2 is based on a central host computer. Access to the host computer is through terminal emulation via the Hanford Local Area Network.

The HMID2 contains the necessary information for determining priority hazardous materials. These priority materials will become the targets of P2/WMin efforts. HMID2 information includes the following:

- Container size

- Container type

- Container unit of measure

- Facility identification

- Facility location - detailed information

- Facility name

- Material name

- Material local name

- MSDS identification

- Reporting representative identification

- Standard pressure

- Standard temperature

- Weight percent of hazardous components.

HMID2 currently does not provide an annual usage of material because materials are updated on a monthly basis and do not take into account daily usage changes. The annual usage of material provided is calculated manually.

\subsection{WASTE TRACKING}

The SWITS is used to identify and track Hanford Site waste streams. The SWITS database provides a "cradle-to-grave" tracking system for the management of radioactive, hazardous, and mixed solid waste in support of generator group waste shippers, transporters, and storage personnel. SWITS also provides the Hanford Site with a data management tool for delivering detailed regulatory compliance information to Federal, state, and local agencies. 
SWITS waste tracking begins at the point of origin. The database collects unique information about each waste container and its contents, including details on physical components, isotopic quantities, and chemical constituents. Waste storage data contained in the SWITS database include container information, container location, and a barcode. Barcodes are used to provide automated facility inventories.

SWITS supports the P2/WMin Program in four ways. First, it is used to extract specific waste generator and generator group data for prioritizing waste streams by quantity, toxicity, and cost. Once priority streams are identified through SWITS, generators and generator groups can work "upstream" to identify the major activities producing the waste and perform opportunity assessments on these activities.

Second, SWITS is used to establish P2/WMin Program performance indicators and goals. The data documents waste reduction from $\mathrm{P} 2 /$ WMin efforts by providing actual waste generation quantities for a given year to compare with waste forecasts for that year. Credit for waste reduction from P2/WMin efforts is adjusted for changes in operations and activities.

Third, SWITS supports the preparation of DOE and EPA waste generation and waste minimization reports. Standard reports on waste generation are being coded into a data system to support reporting to DOE-HQ's Annual Report on Waste Generation and WMin Progress.

Fourth, SWITS provides baseline waste generation data. The baseline helps in establishing priority generator and generator group waste streams to be reduced, and is used as a measure of program progress. The baseline year is 1993 .

\subsection{POLLUTION PREVENTION OPPORTUNITY ASSESSMENT TRACKING}

A P20A tracking system to identify P20A progress and results, and to which activity assessments have been performed, was developed. The P2OA database provides a tool for information exchange by providing key word search capabilities for P20As already conducted. A listing of these P20As is provided on the Hanford Home Page so other generator group programs that conduct P20As on similar activities can view opportunities jdentified or can obtain copies of completed P20As. The system also will identify resource requirements and cost benefits for implementation of P2/WMin opportunities.

\subsection{COST TRACKING AND ACCOUNTING}

\subsubsection{Cost Tracking}

Budget and full time equivalent information from waste generators is collected in quarterly reports. The information is used in the DOE's Annual Report on Waste Generation and Waste Minimization Progress and for quarterly reports to DOE-HQ. 


\subsubsection{Cost Accounting}

Many of the costs and benefits associated with EM and P2/WMin are not readily apparent. The PHMC P2/WMin Program will work to ensure that PHMC personnel who are associated with pollution and waste generating activities have complete information on the full costs and benefits associated with these activities. This will be accomplished primarily through "life-cycle" cost evaluations of options generated from opportunity assessments.

The Hanford Waste Cost Guide is a tool to estimate a "life-cycle" cost of waste generation, treatment, storage, and disposal at the different sites. The total cost per quantity for each waste type and treatability group is used in the evaluation of P2/WMin initiatives through comparing cost savings and payback periods of different initiatives.

The main benefit of this guide is to allow generator groups to determine the projects that are the most cost-effective and that develop high Return-0nInvestment $\mathrm{P} 2 / \mathrm{WMin}$ project proposals. Additionally, waste cost analysis will help to quantify the total effects of proposed or implemented P2/WMin opportunities and give those who develop initiatives a strong technical and financial basis for promoting their idea. 
HNF-EP-0496, Rev. 2

This page intentionally left blank. 
HNF-EP-0496, Rev. 2

\subsection{REPORTING}

\subsection{COMPLIANCE REPORTING}

PHMC generator groups submit annual and quarterly reports to RFSH to support preparation of Sitewide, DOE, and regulatory reporting. Results of the PHMC P2/WMin Program are reported to the EPA and Ecology. The Biennial Report on Waste Minimization is prepared and delivered to Ecology for transmittal to the EPA on even years. In addition to the Biennial report, program activities also are reported in other documents. Some of these are the annual Land Disposal Restrictions Federal Facilities Compliance Act report, the Emergency Planning and Community Right-to-Know Act Section 313 report, and an affirmative procurement progress report.

\subsection{REPORTS TO THE U.S. DEPARTMENT OF ENERGY}

The PHMC P2/WMin Program provides input to and coordinates the preparation of Site input for the DOE Annual Report on Waste Generation and Waste Minimization Progress. This report provides program managers, Site program personnel, and the public with important information on current waste generation and waste minimization at the DOE Sites. Originally mandated by Secretary of Energy Notice SEN-37-92 (DOE 1992), each DOE site is required to provide information on their waste generation that is categorized in ten waste types. Sitewide waste minimization activities and facility-specific waste minimization activities and information also are required, including goals and budget.

The recently issued P2/WMin documentation guide (DOE-RL 1996c) outlines the reporting requirements for PHMC generators.

Quarterly and annual reports are submitted by the PHMC contractors or their generator groups as designated. The quarterly and annual reporting forms include and explain all items to be reported. Quarterly reports are due to the RFSH P2/WMin group January 15, April 15, July 15, and 0ctober 15 . 
HNF-EP-0496, Rev. 2

This page intentionally left blank. 
HNF-EP-0496, Rev. 2

\subsection{SITEWIDE WASTE REDUCTION}

\subsection{TOXICS REDUCTION/MATERIAL SUBSTITUTION}

The Hazardous Materials Reduction Initiative, a centralized system for controlling the procurement of hazardous chemicals, was implemented in FY 1994 and implemented by the RFSH P2/WMin Program. The hazardous chemicals to be controlled include those identified in the original and expanded EPA 33/50 list (Emergency Planning and Community Right-to-Know Act Section 313 report), all ozone-depleting substances included in the Montreal Protocol list (UNEP 1991), and other. EPA- and state-identified hazardous chemicals. No precedence or priority is established for el iminating one hazard over another; hazardous chemicals will be reviewed for product substitution of less hazardous products.

Under FDH P2/WMin policy, subcontractors should consider the review of requests for hazardous materials to determine if a less hazardous substitute may be used or if locally excessed materials are available. The RFSH P2/WMin group has developed a product substitution database that facilitates the substitution process and is shared with other subcontractors.

\subsection{MATERIAL EXCHANGE}

DynCorp Recycle Programs coordinate chemical exchange at the Hanford Site. The program has been very successful at redeploying used chemicals. Most of the Hanford Site large bulk tank chemicals and concentrated chemicals were redeployed by the end of FY 1994. Also, the redeployment of small quantity chemicals is growing as evidenced by the first janitorial supply sale completed late in FY 1994. The Recycle Programs office took a more aggressive approach in FY 1995 by contacting other government agencies regarding the availability of surplus chemicals. The surplus chemicals can be obtained through the state General Services Administration (GSA) office. These activities have continued.

\subsection{RECYCLING/REUSE}

Recycling programs have a successful paper recycling program with 100 percent of all eligible buildings participating. Wood was collected in FYs 1995 and 1996, and the program will continue to grow in FY 1997. A contractor will pick up scrap pallets from the Hanford Site and haul them away for redeployment. Wood that does not meet cleanliness requirements is sent to the local landfill for chipping and subsequent redeployment.

A separate contract for cardboard recycling has been established with collection dumpsters placed and serviced in convenient locations throughout the Hanford Site. The current contract expires in September 1997.

Ecology has approved the operation of a centralized consolidation/ recycling center. This consolidation center manages various types of small batteries, partially filled aerosol cans, non-PCB light ballasts and fluorescent lights. 


\subsection{AFFIRMATIVE PROCUREMENT}

The Secretary of Energy has established an affirmative procurement goal of 100 percent. The RFSH P2/WMin group has provided guidance regarding affirmative procurement in the P2/WMin documentation guide (DOE-RL 1996C) to identify specific items for which affirmative procurement considerations apply.

As a procurement control mechanism, PHMC has two affirmative procurement clauses in their contracts with suppliers to support the purchase of recycled materials. The first clause asks suppliers whether their products are recyclable or contain recycled content. The second clause requires information on the 24 categories of products for which the EPA has established minimum content standards. The categories are paper products, insulation products, cement and cement products, lubricating oils, and tires. Recycled content information is required for these products. Proposals for products that do not meet the minimum content standard may be ineligible for award.

Specific guidance also has been provided to PHMC Procurement by the RFSH

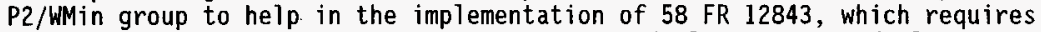
Federal agencies to minimize the procurement of Class I ozone-depleting substances. This guidance directs buyers to review all purchase requests for equipment that may potentially contain such a substance and to seek vendors who can supply equivalent equipment with alternative refrigerants. It also advises Procurement to limit the distribution of store stock items that contain Class I ozone-depleting substances to service and operating groups that demonstrate a need for those materials. 


\subsection{TECHNICAL ASSISTANCE}

Technical assistance will be provided to generators and generator groups to assist the development and implementation of their individual P2/WMin Programs. Assistance that is provided in accordance with this plan and established program guidance manuals will support the development of consistent $\mathrm{P} 2 /$ WMin Programs. Technical assistance will be provided for the following priority program areas and for other program priorities as they are identified.

\subsection{GOAL SETTING}

The recently issued $\mathrm{P} 2$ /WMin documentation guide (DOE-RL 1996c) describes waste reduction goal-setting methodology. Generally, for routine wastes, FDH will establish waste reduction goals. PHMC contractors and subcontractors will establish annual goals for non-routine waste generation activities. The goal-setting guidance encourages generator groups to analyze pollutant releases, waste streams generated, and hazardous material use in their activities. Using this methodology, generator groups will be able to identify their priority hazardous materials, waste types, and pollutants to reduce or eliminate. For non-routine wastes, they will set quantitative goals on the reduction of these materials and streams and will establish schedules and activities to achieve these goals. Goals will provide a basis for establishing resource requirements for generator group programs.

\subsection{BASELINE DETERMINATION}

Waste generation for 1993 has been established as the P2/WMin Program waste generation baseline year. Baselines and projections at the generator, generator group, and PHMC P2/WMin Program level will be used to track program progress and to annually identify priority waste generating activities. Chemical inventories also will be used to establish baseline information on hazardous chemical use.

\subsection{OPPORTUNITY ASSESSMENTS}

A P2OA is one mechanism used to identify and analyze activities for P2/WMin opportunities, and to provide the basis for the development and prioritization of $\mathrm{P} 2 /$ WMin options. These assessments on pollution and waste generating activities are performed by a team of individuals selected for their process knowledge, purchasing and material inventory knowledge, and regulatory and $\mathrm{P} 20 \mathrm{~A}$ expertise. Individuals with expertise in other areas may be added to the team depending on the nature of the process being assessed. 
HNF-EP-0496, Rev. 2

Guidance and training has been developed by the RFSH P2/WMin group to support P20A implementation. Generally, the guidance and training explain how to identify and prioritize waste streams, set goals, select a team, brainstorm ideas, rank P2/WMin initiatives, and begin implementation. The guidance is consistent with the objectives of DOE guidance and the Waste Minimization opportunity Assessment Manual (EPA 1989). The training and guidance will be updated annually or as needed. 
HNF-EP-0496, Rev. 2

\subsection{INFORMATION AND TECHNOLOGY EXCHANGE}

\subsection{SEMINARS, WORKSHOPS, AND MEETINGS}

Meetings with generator and generator group P2/WMin Program coordinators will be held at least quarterly to update coordinators on program activities, management direction, and new program requirements. Technical presentations on $\mathrm{P} 2 /$ WMin techniques will be shared, and coordinators can describe activities they are performing and results they are achieving from their efforts. Additionally, personnel will attend DOE workshops and other forums or conferences to exchange information.

\subsection{ELECTRONIC INFORMATION RESOURCES}

A11 program staff are encouraged to make regular use of the DOE Energy Pollution Prevention Information Clearinghouse, the PNNL Pollution Prevention Information Center, and Enviro\$en\$e Web Server (an EPA Web site).

Another important medium to aid information exchange is the P20A tracking system. Generators and generator groups will be able to search this database for specific information important to their individual activities. A more detailed description of this tracking system is provided in Section 5.3 .

\subsection{OUTREACH AND PUBLIC RELATIONS}

Communicating $\mathrm{P} 2 /$ WMin successes and information to the community through outreach and public involvement will assist in establishing public confidence, increasing awareness of environmental issues, and promoting the reduction of waste. The RFSH P2/WMin Program organizes and participates in activities such as Earth Day and also publishes information externally to help increase awareness and public trust. Additionally, public and stakeholder participation will be sought for applicable projects and program elements to encourage community involvement and to develop a broad base of input to and understanding of relevant $\mathrm{P} 2 /$ WMin issues. The PHMC also provides P2OA assistance to small businesses. 
HNF-EP-0496, Rev. 2

This page intentionally left blank. 
HNF-EP-0496, Rev. 2

\subsection{RESEARCH AND DEVELOPMENT}

Proposals for research and development are expected to arise from the P2/WMin opportunity assessment process described in Section 8.3. Specific proposals for research and development work will be coordinated through FDH to ensure effective allocation of resources. 
HNF-EP-0496, ReV. 2

This page intentionally left blank. 
HNF-EP-0496, ReV. 2

\subsection{PROGRAM EVALUATION}

\subsection{EMPLOYEE PARTICIPATION}

Formal employee evaluation of the program is performed through continual processes for improvement, such as surveys, program strategy discussions, programmatic document reviews, and training evaluations and through program assessments completed by generator group, DOE-RL, or FDH P2/WMin Program coordinators. Employees complete an evaluation after HGET and P2OA training. Valuable comments have been received and the training modules have been improved based on participant comments.

\subsection{POLLUTANT AND WASTE REDUCTION PERFORMANCE}

Ten program performance measures were established in FY 1997. Performance measures are used to track these key activities and progress against them.

Pollutant and waste reduction performance will be evaluated through comparing waste, pollutant, and hazardous material reduction results with goals and 1993 baselines. This evaluation will be performed annually at the PHMC level. 
HNF-EP-0496, Rev. 2

This page intentionally left blank. 


\subsection{REFERENCES}

29 CFR 1910, "Occupational Safety and Health Standards," Section 1910, "Hazard Communication," Code of Federal Regulations, as amended.

58 FR 12843, 1993, "Procurement Requirements and Policjes for OzoneDepleting Substances," Federal Register.

58 FR 12856, 1993, "Federal Agency Compliance with Right-to-Know Laws and Pollution Prevention Requirements," Federal Register.

58 FR 12873, 1993, "Federal Acquisition, Recycling, and Waste Prevention," Federal Register.

58 FR 12902, 1993, "Energy Efficiency and Water Conservation at Federal Facilities," Federal Register.

Comprehensive Environmental Response, Compensation and Liability Act of 1980, as amended.

DOE, 1988, Radioactive Waste Management, DOE Order 5820.2A, U.S. Department of Energy, Washington D.C.

DOE, 1992, Waste Minimization Crosscut Plan Implementation, SEN-37-92, U.S. Department of Energy, Washington, D.C.

DOE, 1994, Waste Minimization/Pollution Prevention Crosscut Plan, DOE/FM-0145, U.S. Department of Energy, Washington, D.C.

DOE, 1996, Pollution Prevention Program P7an, DOE/S-0118, U.S. Department of Energy, Washington, D.C.

DOE-RL, 1990, Hanford P7ant Standards (HPS) Program, D0E-RL Order 6430.1C, SDC 4.1 and SDC 5.1, U.S. Department of Energy, Richland Field office, Richland, Washington.

DOE-RL, 1996a, Hanford Site Waste Minimization and Pollution Prevention Awareness Program Plan, DOE/RL-91-31, Rev. 1, U.S. Department of Energy, Richland Operations office, Richland, Washington.

DOE-RL, 1996b, U.S. Department of Energy, Richland Operations Office, and Fluor Daniel Hanford, Inc. Contract DE-AC06-96RL13200, Purchase Requisition D6-96RL13200.00, U.S. Department of Energy, Richland Operations office, Richland, Washington.

DOE-RL, 1996c, Hanford Site Guide for Preparing and Maintaining Generator Group Pollution Prevention Program Documentation, DOE/RL-95-103, Rev. 1, U.S. Department of Energy, Richland Operations Office, Richland, Washington.

DOE-RL 1996d, Pollution Prevention Opportunity Assessments - A Training and Resource Guide, DOE/RL-96-80, Rev. D, U.S. Department of Energy, Richland Operations office, Richland, Washington. 
Ecology, EPA, and DOE, 1996, Hanford Federal Facility Agreement and Consent Order, as amended, Washington State Department of Ecology, U.S. Environmental Protection Agency, U.S. Department of Energy, 01 ympia, Washington.

Emergency Planning and Community Right-to-Know Act, as amended, 42 USC 11013, 11028 , et seq.

EPA, 1989, Waste Minimization Opportunity Assessment Manual, EPA/625/7-88/003, U.S. Environmental Protection Agency, Washington, D.C.

FDH, 1996, Pollution Prevention and Waste Minimization Policy, FDH-CM-1, Rev. 0, Fluor Daniel Hanford, Inc., Richland, Washington.

PNNL, 1995, A Proposed Framework for Conducting Pollution Prevention Design Assessments (P2DAs) on U.S. Department of Energy Projects, PNL-10204/UC-602, Pacific Northwest National Laboratory, Richl and, Washington.

Resource Conservation and Recovery Act of 1976, as amended, 42 USC 6901 et seq.

Toxic Substances Control Act of 1976, as amended, 15 USC 2601 et seq.

UNEP, 1991, Handbook for the Montreal Protocol on Substances That Deplete the Ozone Layer, Second Edition, United Nations Environment Programme, Nairobi, October 1991.

WAC 173-303, 1991, "Dangerous Waste Regulations," Washington Administrative Code, as amended. 
HNF-EP-0496, Rev. 2

\section{APPENDIX A \\ FLUOR DANIEL HANFORD POLLUTION PREVENTION AND WASTE MINIMIZATION POLICY}

$A-i$ 
HNF-EP-0496, Rev. 2

This page intentionally left blank. 
Fluor Daniel Hanford will conduct operations and activities in a way that minimizes the quantity and toxicity of wastes generated, eliminates or minimizes pollutant releases to the environment, and minimizes the use of toxic substances. This will be done through better design, product acquisition, and changes in technologies, work practices, and procedures.

We are committed to operating an effective Waste Minimization/Pollution Prevention (WMin/P2) program. The FDH WMin/P2 program priorities in descending order are:

1. Source reduction

2. Environmentally safe recycling

3. Waste treatment

4. Environmentally safe disposal.

Waste treatment to reduce the quantity, toxicity, or mobility (or a combination of these) will be considered only when prevention or recycling are not possible or practical. Environmentally safe disposal is the last option.

The FDH WMin/P2 program will comply with the letter and the spirit of current and future WMin/P2 EOs, regulatory requirements, and DOE directives. The program will be based upon the program elements and priorities identified in the 1994 Department of Energy Waste Minimization/Pollution Prevention Crosscut Plan and the 1996 Department of Energy Pollution Prevention Program Plan. Emphas is will be placed on meeting the Secretary of Energy's goals, performing pollution prevention opportunity assessments, implementing both technically and economically practicable opportunities whenever risks will not be shifted from one environmental medium to another, high Return-on-Investment waste minimization projects, and incorporating WMin/P2 into new or modified facility designs.

Management will provide adequate personnel, budget, training, and material to achieve and implement a successful WMin/P2 program. The program will be documented in the FDH WMin/P2 Program Implementation $\mathrm{Plan}$. WMin/P2 will become an integral part of the way work is performed at the Hanford Site. 
HNF-EP-0496, Rev. 2

This page intentionally left blank.

A-2 
HNF-EP-0496, Rev. 2

APPENDIX B

U.S. ENVIRONMENTAL PROTECTION AGENCY WASTE MINIMIZATION PROGRAM ELEMENTS GUIDANCE COMPLIANCE MATRIX 
HNF-EP-0496, Rev. 2

This page intentionally left blank. 
HNF-EP-0496, Rev. 2

\section{U.S. ENVIRONMENTAL PROTECTION AGENCY \\ WASTE MINIMIZATION PROGRAM ELEMENTS GUIDANCE COMPLIANCE MATRIX}

\begin{tabular}{|c|c|}
\hline $\begin{array}{c}\text { EPA Guidance' } \\
\text { Waste Minimization Program elements } \\
\text { (Resource Conservation and Recovery } \\
\text { Act of 1976) }\end{array}$ & Program documentation \\
\hline \multirow{2}{*}{$\begin{array}{l}\text { A. Top management support } \\
\text { Goals }\end{array}$} & \\
\hline & $\begin{array}{l}\text { Hanford Site plan, Contractor } \mathrm{plans} \\
\text { Generator group program } \\
\text { documentation }\end{array}$ \\
\hline $\begin{array}{l}\text { Commitment - opportunity } \\
\text { implementation }\end{array}$ & Hanford Site plan, Contractor plans \\
\hline Facility coordinator & Contractor plans \\
\hline Publicize successes & Hanford Site plan, Contractor plans \\
\hline Incentives & Hanford Site plan, Contractor plans \\
\hline Training & Hanford Site plan, Contractor plans \\
\hline $\begin{array}{l}\text { B. Characterization of waste } \\
\text { generation }\end{array}$ & Contractor plans \\
\hline \multicolumn{2}{|l|}{ C. Opportunity assessments } \\
\hline Identify all opportunities & $\begin{array}{l}\text { Contractor } \mathrm{plans,} \mathrm{Generator} \mathrm{group} \\
\text { program documentation }\end{array}$ \\
\hline Determine true costs of the waste & $\begin{array}{l}\text { Contractor plans, Generator group } \\
\text { program documentation }\end{array}$ \\
\hline D. Cost allocation system & Hanford Site plan, Contractor $\mathrm{plans}$ \\
\hline E. Technology transfer & Hanford Site plan, Contractor plans \\
\hline F. Program evaluation & $\begin{array}{l}\text { Hanford Site plan, Contractor plans } \\
\text { Generator group program } \\
\text { documentation }\end{array}$ \\
\hline
\end{tabular}

${ }^{1}$ Federal Register, Vol. 58, Ho. 102, 1993.

Resource Conservation and Recovery Act of 1976, as amended, 42 uSC 6901 et seq. 
HNF-EP-0496, Rev. 2

This page intentionally left blank. 
HNF-EP-0496, Rev. 2

APPENDIX C

GENERATOR GROUP POLLUTION PREVENTION/WASTE MINIMIZATION PROGRAM DOCUMENTATION 
HNF-EP-0496, Rev. 2

This page intentionally left blank. 
HNF-EP-0496, Rev. 2

\section{GENERATOR GROUP POLLUTION PREVENTION/WASTE MINIMIZATION PROGRAM DOCUMENTATION (DOE-RL 1996c)}

\section{Annual Goals}

2. Budget and Staffing

- Budget and full time equivalent staff supporting Pollution Prevention/Waste Minimization (P2/WMin) activities.

3. Pollution Prevention Opportunity Assessments (P20As)

- Summary waste stream prioritization information - Waste stream information

- Priority waste streams and activities

- Completed P20A worksheets.

4. Pollution Prevention Reporting

- Quarterly reports

- Annual reporting

- Includes:

A. Progress against annual goals and completed P2OAs

B. Certification with plant manager's signature

C. Annual Report on Waste Minimization Accomplishments (forms). 
HNF-EP-0496, Rev. 2

This page intentionally left blank. 
HNF-EP-0496, Rev. 2

\section{DISTRIBUTION}

\section{Number of Copies}

\section{ONSITE}

13

U.S. Department of Energy, Richland Operations office

M. A. Barnard

K8-50

S. D. Bradley

S7-51

C. R. Briggs

A5-55

D. H. Chapin

R3-79

M. S. Collins

A5-18

E. B. Dagan

R. X. Gonzalez

S7-55

M. F. Jarvis

J. Pennock

R. W. Small

J. H. Zeisloft

Hanford Technical Library

Public Reading Room

R3-79

K8-50

$\mathrm{HO}-12$

A2- 45

$\mathrm{HO}-12$

P8-55

$\mathrm{H} 2-53$

3 Bechtel Hanford Inc.

D. K. Duvon

$X 1-86$

E. M. Mueller

H9-01

R. J. Landon

HO- 18

5

B\&W Hanford Company

T. G. Beam

S4-66

J. E. Bramson

T5-54

F. J. Carvo

N1-41

S. W. Hildreth

S6-21

A. E. Hill

N2-57

1

B\&W Protec. Inc.

M. B. Jaeger

L4-02

1

DE\&S Hanford, Inc.

N. O. Hinojosa

$\times 3-67$

Distr-1 
HNF-EP-0496, Rev. 2

DISTRIBUTION (cont.)

6

DynCorp Tri-Cities Services, Inc.

J. F. Brown

G2-06

B. J. Dixon

G3-26

W. S. Dunnivant

G3-09

C. M. Lee

L6-39

K. S. McDowel1

G2-06

R. E. Morgan

G3-26

5

Eluor Daniel Hanford, Inc.

J. R. Best

0 . D. Berglund

T6- 12

R. E. Boykin

J. W. Golden

S0-19

G1-57

N1-26

B. E. Woodford

T5-56

Fluor Daniel Northwest, Inc.

R. A. Det Mar

E6-40

1 Hanford Environmenta1

Health Foundation

S. M. Mcinturff

H1-77

Lockheed Mart in Hanford Corp.

B. L. Treadway

R1-90

2

Lockheed Martin Services. Inc.

Central Files

A3-88

Document Processing Center

A3-94

2

Pacific Northwest National Laboratory

J. A. Engel-Cox

P7-79

K. M. Fowler

K8-03

Rust Federal Services, Inc.

S. E. Myers

Distr-2 
HNF-EP-0496, Rev. 2

\section{DISTRIBUTION (cont.)}

15 Rust Federal Services Hanford, Inc.

S. M. Add 1 eman

T4-04

N. A. Ballantyne

S6-71

M. D. Betsch

H. C. Boynton

M. M. Seay

S. C. Howald

H6-06

T4-52

S6-31

K. K. Kover

H6-06

C. J. Lewis

T3-28

T4-52

D. E. McKenney

H6-06

D. S. Merry

H6-06

D. H. Nichols

H6- 06

B. G. Place

H6-06

J. C. Renner

P. Segall

H6-06

R. W. Szelmeczka

H6-06

L6-05 
HNF-EP-0496, ReV. 2

This page intentionally left blank.

Distr-4 